\title{
Biomimetic stochastic race model in the subcortical saccadic selection processes: a model of the tecto-basal loops
}

\author{
Charles Thurat $^{1 *}$, Steve N'Guyen²${ }^{2}$ Benoît Girard ${ }^{1}$ \\ From Twenty Second Annual Computational Neuroscience Meeting: CNS*2013 \\ Paris, France. 13-18 July 2013
}

Gated accumulators, a.k.a race models, have been successfully used to describe neural selection processes, especially in visual selection [1,2]. The elements competing in the visual field feed evidence to counters, up to some selection threshold: the first counter reaching it is selected. Yet, these models do not explain which neurophysiological mechanism could account for the selection threshold itself, as well as how the activity in the accumulators, after threshold crossing, is transformed into a non-ambiguous motor command.

Thus, we propose to create a model of saccade target selection including the Superior Colliculus (SC) and the Basal Ganglia (BG): their reciprocal connectivity has recently been emphasized [5], as well as their implication in visual selection processes [6]. By creating a model linking together recent SC [7] and BG [8] models, we investigate the possibility that selection in the $\mathrm{SC}$ results from SC-BG interaction rather than purely lateral inhibitions within the $\mathrm{SC}$ and we propose a new role for the Visuo-Motor prelude neurons of the intermediate layers of the SC [4], as noisy evidence integrators for each of the targets presented in the visual input layers. We also propose that the this integrator layer feed the $B G$, and that the BG disinhibitory feedback modulates the rate of integration in order to stochastically bias the selection process when targets of similar saliences compete. A second feedback loop from the BG to the SC applies direct inhibition to the ouptut of the integration layer to the deepers layers of the SC, and will selectively disinhibit only the winning target and suppress the activity of the distractors or unselected targets, so that

\footnotetext{
* Correspondence: thurat@isir.upmc.fr

${ }^{1}$ ISIR, CNRS-UPMC, Pierre et Marie Curie university, Paris, France

Full list of author information is available at the end of the article
}

the deep motor layer of the SC can produce an unbiaised motor command to the eyeplant.

Our model's architecture offers a mechanism of gluing of the two hemifields for near-vertical saccades, and is able to reliably reproduce selection data and neurons activity profiles gathered in-vivo [3,4], by selecting one target among several distractors of inferior salience as well as one target among several other targets of similar salience. Furthermore, the model provides specific temporal and spatial discrimination predictions that can be tested in-vivo.

\section{Acknowledgements}

The authors acknowledge the funding of the HABOT project, Emergence(s) program of the Ville de Paris.

\section{Author details}

${ }^{1}$ ISIR, CNRS-UPMC, Pierre et Marie Curie university, Paris, France. ${ }^{2}$ LPPA, CNRSCollège de France, Paris, France.

Published: 8 July 2013

\section{References}

1. Bundesen C: Visual attention: Race models for selection from multielement displays. Psych Res 1987, 49:113-121.

2. Ludwig CJ, Mildinhall JW, Gilchrist ID: A population coding account for systematic variation in saccadic dead time. J Neurophysiol 2007, 97(1):795-805.

3. McPeek RM, Keller EL: Saccade Target Selection in the Superior Colliculus During a Visual Search Task. J Neurophysiol 2002, 88:2019-2034.

4. McPeek RM, Keller EL: Deficits in saccade target selection after inactivation of superior colliculus. Nature Neuroscience 2004, 7(7):757-763.

5. McHaffie JG, Coizet V, Redgrave P: Subcortical loops through the Basal Ganglia. Trends Neurosci 2005, 28(8):401-407.

6. Arai K, Keller EL: A model of the saccade-generating system that accounts for trajectory variations produced by competing visual stimuli. Biol Cybern 2005, 92:21-37.

7. Tabareau N, Bennequin D, Berthoz A, Slotine JJ, Girard B: Geometry of the superior colliculus mapping and efficient oculomotor computation. Biol Cybern 2007, 97:279-292. 
8. Girard B, Tabareau N, Pham QC, Berthoz A, Slotine JJ: Where neuroscience and dynamic system theory meet autonomous robotics: A contracting basal ganglia model for action selection. Neur Netw 2008, 21:628-641.

doi:10.1186/1471-2202-14-S1-P145

Cite this article as: Thurat et al:: Biomimetic stochastic race model in

the subcortical saccadic selection processes: a model of the tecto-basal loops. BMC Neuroscience 2013 14(Suppl 1):P145.

Submit your next manuscript to BioMed Central and take full advantage of:

- Convenient online submission

- Thorough peer review

- No space constraints or color figure charges

- Immediate publication on acceptance

- Inclusion in PubMed, CAS, Scopus and Google Scholar

- Research which is freely available for redistribution

Submit your manuscript at www.biomedcentral.com/submit 